\title{
Muslim Americans
}

A guide to online resources

S nce the terrorist attacks on September 11, 2001, many American Muslims have been negatively stereotyped, even vilified, in the United States. Numerous U.S. citizens began associating those horrible events, committed by a small group of violent foreign extremists, with Muslim Americans who live peaceful and productive lives. The effects of this fear, bias, and scrutiny are long-term and pervasive. Last fall, former presidential candidate Herman Cain made discriminatory comments about Muslim Americans for which he later apologized. Not long after, Lowe's Home Improvement made news for pulling its advertising from the TLC reality show All-American Muslim. This March, New York's Mayor Michael Bloomberg and Police Commissioner Raymond Kelly defended surveillance of Muslim businesses, mosques and students after the Associated Press covered these activities in a series of articles. The controversy about a proposed mosque near Ground Zero, still unresolved, receives massive media coverage. Indeed, any incident occurring here or abroad that is related or credited to Islamic extremism seems to adversely affect U.S. public opinion of Muslim Americans.

There are numerous authoritative Internet resources that focus on Muslim American philosophies, attitudes, and lives. Space restrictions made decisions about what to include and what to exclude especially challenging. These sites were selected for a number of reasons including their uniqueness and thoroughness, and their combination of information for both Muslim and non-
Muslim Americans. A sample of some recent scholarly research is also included. All of these resources highlight how September 11 dramatically altered the lives of Muslim Americans due to widely perceived associations with Islamic terrorism worldwide and the widespread fear that results.

\section{Organizations}

- CAIR: Council on American-Islamic Relations. CAIR was established in 1994 to promote awareness of Islam in the United States and "empower American Muslims." This Web site offers a significant array of information for people interested in learning about Islam. An Employer's Guide to Islamic
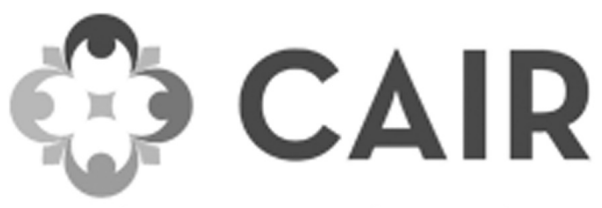

\section{Council on American-Islamic Relations}

Religious Practices is one of several online publications, and the "American Muslims" link leads to the association's statement denouncing terrorism. It also provides many important resources for Muslims. Links to content specifically for Muslim Americans, for example, lead to a range of clear explanations of civil rights, lists of relevant federal legislation, and a variety of news items, press releases, and a "CAIR Community Tool Kit" with detailed

Allison A. Cowgill is head of reference at California State University-Fresno, e-mail: acowgill@csufresno.edu ๑) 2012 Allison A. Cowgill 
information on how to combat bigotry at the local level. This site also includes a search box. Access: http://www.cair.com/.

- Islamic Relief USA: Working Together for a Better World. Founded in 1993, this well-known humanitarian organization is an independent affiliate of Islamic Relief Worldwide. It is involved in a variety of projects in 34 countries, including Afghanistan, Bosnia, Chad, Pakistan, Haiti, Somalia, and the United States. Islamic Relief USA's programs focus on education initiatives, food aid, health, and water and sanitation. The Web site offers links to information on the group's history, mission, frequently asked questions, grants, special fundraising events, videos, a blog, and how to volunteer and make donations. PDF files of its publication Partnership are available from 2004 through 2011. Access: http:// www.irusa.org/.

- ISNA: Islamic Society of North America. ISNA, originated in 1982 as an offshoot of the Muslim Student Association, is one of the largest Muslim American membership organizations in

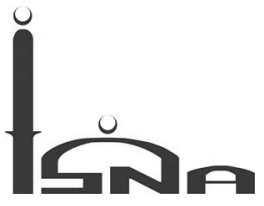
the United States. The group's primary goals include improving the well-being of Muslim Americans and "building bridges of understanding and cooperation" both within and outside Islamic communities. This Web site offers an enormous variety of information, including recent full-text news items; press releases; conferences and special events updates; the Qur'an translated into English, French, and German; and services that combat domestic violence and addiction. ISNA is also involved in a variety of humanitarian efforts in locations such as Darfur and Southeast Asia. Islamic Horizons, its bimonthly publication, is covered later in this article. A single search box provides access to specific topics and it offers online e-newsletter subscriptions. Access: http://www.isna.net/.

- Muslim Public Affairs Council: MPAC. This organization, created in 1988, focuses on improving U.S. sentiment towards
Muslim Americans and ensuring their civil liberties. It promotes such Islamic core values as love of God and hatred of terrorism. This Web site offers a vast amount of information, including the group's history, vision and mission, press releases, full-text policy reports, programs and events, recommended books, and issue statements on such topics as civil rights, "Islamophobia," and freedom of religion in the United States. MPAC's core belief is that "change ... requires organized, sustained efforts" both locally and nationally. Access: http://www.mpac.org/.

- Muslim Students Association (MSA). MSA was established in 1963 to support Muslim student success in higher education and promote networking and unity. The MSA Web site includes information about the organization's "guiding principles," regional and national conferences, special events such as Islam Awareness Day, individual chapters nationwide, a blog, multi-media, and a variety of resources under such headings as "Make Your Campus More Muslim Friendly" and "Learning Professional MSA Management Skills." It also provides links to the MSA National E-letter from 2008 to date. Access: http://msanational.org/.

\section{Reports}

- "The American Mosque 2011: Basic Characteristics of the American Mosque, Attitudes of Mosque Leaders." This thorough survey, released in January 2012, reports that there are more than 2,000 mosques in the United States, and that more than 2.6 million Muslims, from very diverse backgrounds, attend their services. This report covers findings from 524 telephone interviews of select mosque leaders, the majority of whom do not believe that "overall American society is hostile to Islam" and "agree that Muslims should be involved in American institutions." It includes a range of statistics on such topics as the locations of mosques, kinds of facilities, and the ethnicity and gender of regular attendees. Ihsan Bagby, University of Kentucky professor of Islamic Studies, is listed as both the author and one of the survey's research- 
ers. Access: http://www.cair.com/Portals/0 /pdf/The-American-Mosque-2011-web.pdf.

- "Anti-Terror Lessons of MuslimAmericans." Duke University's David Schanzer and Ebrahim Moosa, and University of North Carolina's Charles Kurzman issued this 64-page report in March 2010. It details the results of their research on radicalized Muslim Americans after September 11, and how Muslim Americans combat such radicalization. While perceptions of anti-Islamic discrimination in the Muslim-American community have increased, the authors found that few individuals were actually involved in terrorist activities in the preceding ten years and that Muslim American communities have successfully limited radicalization in a variety of ways, including condemning violence; engaging in local "self-policing;" building communities that lessen "social isolation;" and promoting "political engagement" at all levels in the United States. This study includes an executive summary, recommendations, statistics on "terrorism offenders," several charts, and bibliographic references. Access: http://www.sanford. duke.edu/news/Schanzer_Kurzman_Moosa _Anti-Terror_Lessons.pdf.

- "The 'Bin Laden' Effect: How American Public Opinion About Muslim Americans Shifted in the Wake of Osama Bin Laden's Death." Ohio State University Professors Erik Nisbet and Michelle Ortiz collaborated with Cornell University's Yasamin Miller and University of New Hampshire's Andrew Smith on this 18-page report. They telephoned a sample of Americans to measure their perceptions of Muslim Americans from April 7, 2011, through May 24, 2011. Osama Bin Laden's death occurred after the project's first three weeks, which allowed the researchers to compare responses recorded before and after he was killed. They discovered that this event very negatively affected public opinion due to the massive media coverage it received. After Bin Laden was killed, people were more resentful and fearful of Muslim Americans, and supported increased limitations on their civil liberties. An executive summary, other significant findings, and an explanation of the methodology are included. Access: http://www.eriknisbet.com /files/binladen_report.pdf.

- "Muslim Americans: Faith, Freedom, and the Future." The Gallup Center for Muslim Studies and the Abu Dhabi Gallup Center issued this 132-page report, subtitled "Examining U.S. Muslims' Political, Social, and Spiritual Engagement 10 Years After September 11," in August 2011. This poll measured tolerance, religious practices, and civic interactions, comparing results to other major religious groups in the United States. Numerous graphs clearly highlight a variety of findings that indicate, for example, that a majority of the Muslim Americans polled "are satisfied with their current lives;" have definite views on how the Middle East conflict should be resolved; do not support al Qaeda; and while loyal to the United States, believe that military involvement in Afghanistan and Iraq is a mistake. This report also includes an executive summary, recommendations for future action, and an explanation of the methodology used. Access: http://www. abudhabigallupcenter.com/148772/REPORTMuslim-Americans-Faith-Freedom-Future. aspx.

\section{PewResearchCenter}

- "Muslim Americans: No Signs of Growth in Alienation or Support for Extremism." This August 2011 Pew Research Center publication reports on a survey of more than 1,000 Muslim Americans completed last year. Researchers focused on determining how "political and social attitudes" changed since the 2007 Pew Research Center survey "Muslim Americans: Middle Class and Mostly Mainstream." This effort used the same methodology and most of the questions from 2007 resulting in useful and valid comparisons. Sections cover topics such as demographics, religious practices, challenges, and concerns about terrorism and international relations. Findings note, for example, that Muslim Americans increasingly believe they are viewed suspiciously and that mosques 
and Islamic centers face growing hostility in their communities. Nevertheless, the Muslim Americans surveyed "have not become disillusioned" and are "overwhelmingly satisfied" with their lives. This 137-page work includes numerous charts and graphs, and a thorough explanation of the methodology used. Access: http://www.people-press.org/files/legacy -pdf/Muslim-American-Report.pdf.

\section{Media}

- The American Muslim (TAM). Originating as a quarterly print periodical in 1989, The American Muslim became a completely online effort in 1995. The publishers are "dedicated" to supporting peace, justice, and "inter-community dialogue." The site has links to topics arranged by subject, a list of recommended books on Islam, news items, and full-text articles from other sources. Clicking on the icon "Muslims Denounce Terrorism: Terror Has No Religion" takes users to a long list of links to "Muslim denunciations of terrorism, extremism, and violence." Very recent articles are also listed by title and arranged by date on the right side of the page. A search box is provided for additional access to site content. The editors stress that TAM is not affiliated with the Muslim American Society or their similarly titled publications. Access: http://www.theamericanmuslim.org/.

- Islamic Horizons. The Islamic Society of North America publishes this bimonthly journal. Full-text issues from November/ December 2008 to date are available online in PDF. The site offers a search box, and results can be limited to keywords or exact phrases and specific categories, such as articles, sections, and news feed. The January/ February 2012 issue's cover story discusses the challenges young Islamic adults face as they balance their religious beliefs with their lives in the United States. The rest of this issue primarily focuses on educational topics, including Islamic schools, the relationship between school and family, and American Muslims in higher education. Access: http://www.isna.net/Islamic-Horizons/pages /Islamic-Horizons.aspx.
- Muslim Observer. This weekly newspaper, headquartered in Michigan and distributed nationwide, covers a wide array of local, national, and international news on Muslims and Islam. The most recent issue is available full-text online, and clicking on "Archives" takes users to a site map that provides links to back issues from November 2004 to date; to content arranged by subject; and to specific newspaper sections such as op-ed and editorials. Keyword searching is available to help users readily find articles on specific topics. Access: http://muslimmedianetwork. $\mathrm{com} / \mathrm{mmn} / \mathrm{p}=50$.

- NPR: National Public Radio. This Web site provides a search box that allows users to find more than 175 NPR programs and news stories on "Muslim Americans" (use quotation marks to get the most precise results) as far back as the mid-2000s. Results are ranked either by date or relevance. Recent entries include the Morning Edition report titled "Muslim Americans Question Scrutiny at the Border," the Talk of the Nation segment titled "How Being Muslim in America Has Changed Since 9/11," and the Tell Me More broadcast "Obama Gets Heat for Quran-Burning Apology." Access: http://www.npr.org/.

- Times Topics: Muslim-American News. This authoritative site provides free access to more than 350 full-text New York Times articles about Muslim Americans from 2000 to date. The homepage provides "Highlights from the Archives," arranged by headlines that can be organized either by date or by relevance. A search box at the bottom of the screen allows readers to use keywords to find articles on specific subjects. Photographs are included. Access: http://topics.nytimes.com /topics/reference/timestopics/subjects/m /muslimamericans/index.html.

\section{U.S. government sources}

- Being Muslim in America. The Bureau of International Information Programs, U.S. Department of State, published this 60-page document in 2009 to describe American Islam culture and life, and help dispel existing American stereotypes of Muslim Americans. 
It includes numerous photographs of people engaged in everyday activities, profiles of young Muslim Americans who have successful careers, basic demographic statistics, a timeline of Muslim history in the United States, and brief biographies of prominent Muslim Americans and their contributions to America. Access: http://www.america.gov /media/pdf/books/being-muslim-in-america. pdf\#popup.

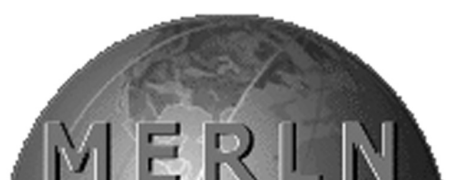

- U.S. Relations with the Muslim

World. The Military Education Research Library (MERLN) mounted a huge collection of links to a wide variety of resources on the relations between Muslims and the United States. Included are U.S. government "official" statements, Congressional hearings, special reports, and research done by organizations such as the Carnegie Endowment for International Peace and the Brookings Institution. The time frame is 2001 through 2011. Although this site is decidedly more international than domestic in scope, it is included because federal actions and policies influence and reflect America's complex relationships with Muslims both here and abroad. While the National Defense University Library maintains this site, a group of "military education research libraries" collaborate on its content. Access: http:// merln.ndu.edu/index.cfm?type $=$ section $\&$ seci $\mathrm{d}=265$ \&pageid $=35$.

\section{Note}

1. Pew Research Center survey Muslim Americans: Middle Class and Mostly Mainstream, www.people-press.org/files/legacy -pdf/329.pdf). $n$

\section{("Cornering the information market," cont. from page 266)}

efforts can aid us in our self-reflection, and incorporating popular culture can facilitate students' understanding of what we're about: Miller Library's table at the academic resource fair attempted to do both.

\section{Notes}

1. Paige Jaeger, "Metacognition and learning in the library," Library Media Connection, November-December 2007, http:// static.schoolrack.com/files/20261/218668/ library_diff_instr.pdf (accessed April 5, 2012).

2. Melissa Gross and Don Latham, "Attaining information literacy: An investigation of the relationship between skill level, selfestimates of skill, and library anxiety," Library E Information Science Research (07408188) 29 (3) (09): 332-53.

3. Alison J. Head and Michael Eisenberg, "Truth Be Told: How college students evaluate and use information in the digital age," (Seattle, WA: Project Information Literacy
Progress Report, The Information School, University of Washington, November 1, 2010), http://projectinfolit.org/pdfs/PIL_Fall2010_ Survey_FullReport1.pdf (accessed April 5, 2012).

4. Unfortunately, we had no way to assess how effective the game was in terms of the retention of this new knowledge. One way to begin to assess this would be to use the game as a training device for new student workers, a suggestion that was made by a colleague. Our sample would be skewed by the fact that these students willingly volunteer to work at the library, but a more systematic exploration of the game would provide opportunities to measure how effective the game is in concrete terms. More players and more opportunity to measure their retention of knowledge would be optimal in terms of gauging how much students can learn over the longer term, when using this type of educational scaffolding. $n$ 